\title{
INTERAKSI SOSIAL SUKU SAMIN DENGAN MASYARAKAT SEKITAR (STUDI DI DUSUN JEPANG DESA MARGOMULYO KECAMATAN MARGOMULYO KABUPATEN BOJONEGORO TAHUN 1990-2012)
}

\author{
Khoirul Huda \& Anjar Mukti Wibowo*
}

\begin{abstract}
Abstrak
Penelitian ini bertujuan untuk mengetahui bentuk-bentuk interaksi sosial Suku Samin dengan Masyarakat Sekitar di Dusun Jepang Desa Margomulyo Kecamatam Margomulyo Kabupaten Bojonegoro Tahun 1990-2012. Adapun bentuk dari penelitian ini adalah penelitian kualitatif yang datanya menekankan pada kondisi obyek yang alamiah untuk memahami dan menafsirkan makna peristiwa hubungan interaksi pola tingkah laku, dan tidak ada rekayasa dalam aktifitas tersebut saat penelitian berlangsung. Pengambilan data melalui sumber data primer diperoleh dari wawancara dengan informan, dan sumber data sekunder diperoleh dari dokumen Desa Margomulyo, dokumen sejarah Samin dan bahan kepustakaan maupun jurnal ilmiah. Validasi yang digunakan yaitu validasi sumber dan teknik. Analisis data yang digunakan adalah analisis data model interaktif Miles dan Huberman.

Berdasarkan hasil penelitian dapat diketahui bahwa keberadaan masyarakat Samin telah mengalami transisi dari tradisional menuju masyarakat modern, dan terwujud dalam bentuk interaksi asosiatif dan disosiatif. Bentuk asosiatif berupa kerjasama seperti gotong royong, musyawarah, dan membantu ketika ada yang memerlukan. Bentuk disosiatif yakni konflik seperti terjadi kesalahpahaman misalnya ada kecemburuan sosial ketika adanya bantuan dari pemerintah pusat yang terkadang membuat kedua belah pihak ada rasa iri. Selain itu pengaruh yang terjadi bersifat positif maupun negatif, bagi Samin perubahan positif seperti gaya hidupnya dan pola/cara berpikir yang modern, sedangkan pengaruh negatifyaitu tradisi dan budaya Samin mulai sedikit terkikis dan ditinggalkan. Bagi masyarakat akan mengetahui karakter orang Samin dan dalam berkomunikasi terkadang mereka berhati-hati, sebab orang Samin mudah tersinggung serta nilai Saminisme yaitu kejujuran juga sedikit terbawa dalam kehidupan masyarakat saat ini. Kata Kunci : Interaksi Sosial, Suku Samin, Masyarakat
\end{abstract}

\section{Kata Kunci : Interaksi Sosial, Suku Samin}

\section{Pendahuluan}

Pada dasarnya manusia secara kodrati tidak bisa lepas dari pola hidup berkelompok. Hal ini juga didasarkan bahwa manusia adalah makhluk sosial, yang akan membutuhkan bantuan dari manusia lain. Pola hidup berkelompok terjadi akibat dari sifat dasar manusia yang mempunyai keinginan hidup bersama manusia lain dan membangun sistem kehidupan, di dalamnya ada tatanan nilai, norma dan tujuan bersama. Selain itu, manusia juga memiliki atau berkeinginan untuk dapat bergabung dengan lingkungan sekitarnya. Dengan sendirinya dari berbagai manusia akan membentuk sebuah masyarakat yang nantinya terbentuk juga struktur sosial. Masyarakat sebagai suatu ikatan bersama dan hidup selama bertahun-tahun dalam lingkungan tertentu akan mengalami perubahan maupun perkembangan. Hal ini dapat dikatakan perubahan itu muncul karena suatu anggota masyarakat melakukan hubungan (interaksi sosial) 
dengan yang lain. Sudah barang tentu, interaksi itu dapat mengarah pada hubungan yang terbuka maupun tertutup.

Hal tersebut juga dikemukakan oleh Von Wiese (dalam Hassan Shadily, 1993: 97) bahwa hubungan terbuka itu tidak tertutup oleh suatu hubungan lain maupun tidak ada yang disembunyikan, sebaliknya hubungan tertutup (berkedok) dimana hubungan ini bersifat tidak tegas karena tertutup oleh hubungan lain, sehingga menutup maksud hubungan yang sebenarnya. Hal ini dapat dikatakan pula bahwa keberadaan interaksi dalam masyarakat tersebut memunculkan suatu gerak atau bentuk masyarakat yang mengarah pada sikap yang positif bilamana adanya saling terbuka satu sama lain. Keterbukaan ini bisa saja diwujudkan dalam ranah kerja sama, gotong royong maupun yang lain. Tentu hal ini bisa saja terjadi pada masyarakat Indonesia yang memiliki banyak berbagai budaya maupun suku bangsa. Masyarakat Indonesia sangat beragam bentuknya. Keberagaman ini akan memunculkan statement bahwa indonesia merupakan bangsa yang majemuk.

Amri Marzali (2005: 213) bahwa Indonesia merupakan sebuah masyarakat Negara yang secara antropologis, terdiri dari 500 suku bangsa dengan ciri-ciri bahasa dan kultur tersendiri, bahkan dapat dikatakan mempunyai satu daerah asal, pengalaman sejarah dan nenek moyang. Hal ini dapat dijabarkan bahwa terbentuknya suku dirasa akibat dari adanya kesamaan identitas, budaya yang sama serta ciri hidup secara tradisional seperti kekerabatan maupun agama dijaga dengan erat oleh kelompok tersebut serta biasanya hidup dalam suatu wilayah tertentu dalam jangka waktu lama. Di sisi lain, Indonesia sendiri juga merupakan masyarakat yang multietnis dengan lebih dari 1000 etnis atau subetnis (Leo Suryadinata dkk, 2003: 6). Etnis maupun suku ini mendiami berbagai daerah maupun provinsi di Indonesia yang biasanya bertempat di daerah pemukiman, jauh dari hiruk pikuk masyarakat lain seperti suku Samin yang terdapat di Bojonegoro.

Suku Samin terletak di Dusun Jepang Desa Margomulyo Kecamatan Margomulyo Kecamatan Margomulyo Kabupaten Bojonegoro. Menurut Tashadi (dalam Purwantini dkk, 2000: 9) Samin itu sendiri termasuk etnis jawa yang memiliki paham Manunggaling kawulo gusti. Paham tersebut dapat diartikan sebagai pandangan yang menitikberatkan pada melekatnya sifat-sifat ketuhanan pada diri manusia. Pada dasarnya paham ini menekankan untuk mengajarkan orang berbuat baik, bekerja keras dan sabar serta meninggalkan segala sifat-sifat keburukan. Di sisi lain, dalam dialek bahasa sehari-hari, orang samin cenderung tegas. Artinya, ketika berbicara orang harus mengatakan apa adanya, tidak usah macam-macam, dan disini lebih menekankan pada upaya untuk 
mengutarakan suatu maksud harus sesuai dengan keadaan sebenarnya. Lebih lanjut, sikap maupun tingkah laku mereka cenderun polos, lugu dan mudah tersinggung. Dari kenyataan tersebut, masuk akal bilamana orang luar menganggap suku Samin maupun keturunannya tergolong unik. Disamping itu dapat dilihat bahwa masyarakat Samin memiliki batas-batas yang kuat, dengan memungkinkan interaksi minimal dengan orang luar (Abd. Syukur Ibrahim dalam Sri Wiryanti \& Laksono, 2010: 4).

Sehubungan dengan itu, keterkaitan interaksi suku Samin dengan masyarakat lainnya perlu dijabarkan lebih mendalam. Hal ini dikarenakan keabnormalan baik sikap, tingkah laku dan juga kondisi sosial orang Samin masih terlihat dalam kehidupan bermasyarakat. Oleh sebab itu menarik untuk dikaji lebih lanjut, terkait pada proses interaksi masyarakat suku Samin di Dusun Jepang tahun 1990-2012, yang hakekatnya sekitar tahun 1990-an masyarakat Samin telah mengalami transisi pada sebuah perubahan masyarakat terbuka dan proses pembauran dengan masyarakat lainnya. Permulaan keterbukaan mereka telah terlihat sejak tahun 1967, yang diyakini Indonesia telah benar-benar merdeka, dan secara otomatis akan pengikut dan keturunannya diserukan untuk taat pada pemerintah sendiri, tentu juga dalam kemauan mereka untuk membaur dengan masyarakat secara luas.
Meskipun demikian dekade 1990-an proses interaksi yang dilakukan dalam intensitas yang cukup rendah, sebab sedikit masih ada ketakutan serta kecanggungan untuk bergaul secara luas dan perkembangan ilmu pengetahuan dan teknologi kurang begitu berkembang dengan pesat.

Kenyataannya berbeda saat dekade tahun 2000 hingga sekarang yang notabene keterbukaan suku Samin dengan masyarakat cenderung dalam intensitas tinggi sebab keseringan mereka dalam berinteraksi dengan masyarakat luas. Hal ini juga didukung oleh SDM keturunan Samin cukup baik dengan ada kemauan untuk mengenyam di bidang pendidikan, dan tidak mungkin perubahan untuk berinteraksi antara suku Samin dengan orang lain tentu didorong oleh tuntutan zaman yang mengharuskan segala perubahan itu terjadi. Sudah tidak dapat dielakkan lagi bahwa masa tahun 2000-an frekuensi dalam bergaul dan berinteraksi dengan masyarakat sekitar semakin sering dan akan menunjukkan sikap bergantung dan saling membutuhkan meskipun adanya perbedaan suku Samin yang memiliki pandangan hidup maupun pola pikirnya dengan masyarakat sekitar yang hidup seperti saat sekarang. Oleh karena itu menarik untuk diteliti lebih mendalam, berkaitan dengan bentuk interaksi dan proses interaksi masyarakat Samin dengan sekitarnya di Dusun Jepang pada Tahun 1990-2012. 


\section{Tujuan Dan Manfaat Penelitian}

Penelitian ini bertujuan untuk mengetahui:

1. Bentuk interaksi suku Samin dengan masyarakat sekitar di Dusun Jepang Desa Margomulyo tahun 1990-2012

2. Pengaruh interaksi yang ditimbulkan antara suku Samin dengan masyarakat sekitar di Dusun Jepang Margomulyo tahun 1990-2012

Penelitian ini diharapkan dapat bermanfaat oleh berbagai pihak diantaranya:

1. Bagi Program Studi Pendidikan Sejarah IKIP PGRI Madiun

Penelitian ini dapat memberikan sumbangsih dalam bahan kajian sejarah lokal khususnya suku Samin dan tidak asing dengan keberadaannya.

2. Bagi Masyarakat Sekitar Wilayah Margomulyo

Dapat berguna untuk menambah informasi dalam studi masyarakat mengenai suku samin khususnya di Dusun Jepang Desa Margomulyo

3. Bagi Pemerintah Kabupaten Bojonegoro Penelitian ini dapat memberikan gambaran tentang kehidupannya serta diharapkan agar memberi perhatian berupa bantuan materiil dan non materiil.

\section{Tinjauan Pustaka}

\section{A. Masyarakat}

\section{Pengertian Masyarakat}

Secara etimologis masyarakat berasal dari bahasa Inggris (society) berarti "kawan". Ada sebutan kata masyarakat dari bahasa arab Syaraka yaitu ikut serta, berpartisipasi. Konsep masyarakat memiliki pengertian atau makna yang cukup beragam. Menurut Nursid Sumaatmadja (2010: 35) masyarakat merupakan kelompok manusia yang melakukan antar hubungan, sedikit banyak bersifat kekal, berlandaskan perhatian dan tujuan bersama, serta telah melakukan jalinan berkesinambungan dalam waktu yang lama. Adanya tujuan bersama dalam kelompok tersebut dirasa karena adanya hubungan manusia satu dengan yang lain. Hal ini dapat dikatakan, hubungan itu sudah berlangsung cukup lama dan tentu secara tidak langsung akan tercipta ikatan-ikatan sosial yang tinggi.

Lebih lanjut, masyarakat dipandang sebagai kesatuan hidup manusia yang berinteraksi sesuai sistem adat-istiadat tertentu secara kontinyu dan terikat oleh rasa identitas bersama (Koentjaraningrat, 2009: 118). Keterikatan rasa identitas yang terjadi bermula saat manusia itu hidup bersama di dalamnya ada saling berinteraksi dengan manusia lainnya. Pada saat melakukan interaksi tentu akan menyesuaikan dengan aturan yang sudah terlaksana dan berlangsung dalam masyarakat itu. Tentu keberlangsungan ini secara berkesinambungan dan telah terjalin 
sejak lama serta hakekatnya akan muncul rasa identitas yang sama.

Dari pendapat diatas, dapat dijelaskan bahwa masyarakat merupakan suatu kelompok manusia yang telah hidup bersama-sama dalam relatif waktu cukup lama, dan di dalam hidup bersama itu ada tujuan dikarenakan terikat oleh rasa identitas bersama serta hubungan (interaksi) satu dengan lainnya. Di samping itu individu-individu tersebut juga ada kesadaran diri terhadap posisinya sebagai anggota dari masyarakat, lama kelamaan akan terbentuk suatu sikap dan perasaan yang sama serta struktur sosialnya.

\section{Karakteristik Masyarakat}

Terlepas dari keberagaman pengertian masyarakat di atas, tentu akan dapat dilihat berdasarkan karakteristik tersendiri. Karakteristik tersebut seperti yang diutarakan oleh Dadang Supardan (2008: 28) bahwa masyarakat:

a. Merupakan manusia yang hidup bersama.

b. Bercampur untuk waktu yang lama.

c. Mereka menyadari akan kesatuan maupun perbedaan.

d. Mereka merupakan suatu sistem hidup bersama.

Konsep ini menunjukan bahwa karakteristik masyarakat adalah sekumpulan manusia yang menjalin kehidupan bersama dan relatif jangka waktunya cukup lama. Di dalam jangka waktu tersebut tentu akan terjadi saling berinteraksi dengan manusia lainnya, dengan sendirinya akan tercipta sebuah sistem peraturan yang terbangun dari manusia itu seperti nilai maupun norma. Hal ini dapat diasumsikan bahwa tidak ada kelompok manusia yang dapat berlangsung hidup tanpa norma, sebab norma memungkinkan adanya kehidupan sosial dengan cara membuat suatu perilaku dapat diprediksikan, dengan kata lain tanpa norma kita akan mengalami suatu kekacauan sosial (Syahrial Syarbaini dan Rusdiyanta, 2009: 86).

Hal senada juga disampaikan oleh Horton dan Hunt (dalam Suratman dkk, 2010: 139) menyatakan konsep masyarakat adalah:

a. Kelompok manusia

b. Sedikit banyak memiliki kebebasan dan bersifat kekal

c. Menempati suatu kawasan

d. Memiliki kebudayaan

e. Memiliki hubungan dalam kelompok yang bersangkutan.

Di dalam penjelasannya, karakteristik masyarakat terletak pada suatu kelompok manusia yang mendiami kawasan tertentu, dimana anggota manusia saling mengadakan hubungan timbal balik untuk bertukar pandangan maupun pola hidupnya, nantinya lambat laun akan menghasilkan kebudayaan sendiri. serta berhak memiliki kebebasan sendiri serta cenderung bersifat kekal. 
Dari beberapa ulasan tersebut, secara sederhana karakteristik masyarakat dapat dijabarkan bahwa sekumpulan orang maupun manusia yang terbentuk sejak lama berdasarkan persamaan tujuan, dan menempati suatu wilayah tertentu, di dalamnya terdapat perbedaan-perbedaan baik usia, jenis kelamin maupun latar belakang pendidikan, ekonomi dan sosial. Di dalam perkembangannya mengadakan hubungan secara berkesinambungan satu sama lain sehingga akan memunculkan perasaan identitas dan struktur sosial berupa norma ataupun nilai tersendiri dan sudah barang tentu mempunyai kebudayaan baik tradisi, sistem kepercayaan maupun yang lainnya.

\section{Bentuk-Bentuk Masyarakat}

\section{a. Masyarakat Tradisional}

Masyarakat tradisional merupakan masyarakat bersifat tradisional yang ditandai dengan pola kehidupannya berkelompok dan sistem kekerabatanya yang masih erat, serta mata pencahariaannya cenderung mengarah pada sektor pertanian. Titi Mumfangati dkk (2007: 4) menambahkan segala aspek kehidupannya erat berhubungan dengan lingkungan dan sifatnya yang agraris tentu akan tergantung dengan alam sekitarnya.

Pada hakekatnya karakteristik masyarakat tradisional dapat ditelusuri menurut enam kategori diantaranya pertama bentuk pemilikan yaitu adanya keterikatan pada status sosial secara turun temurun, kedua mekanisme pekerjaan yang kenyataannya belum ada dan biasanya menggunakan alat secara sederhana, ketiga ciri tenaga kerja yang mengarah pada perbudakan atau hamba pengolahan tanah. Keempat cara distribusi ekonomi (pasar) cenderung dibatasi oleh rintangan pajak, perampokan, terbatasnya lembaga keuangan serta transportasi yang buruk, kelima hukum yang berlaku biasanya bersifat khusus dan penerapannya berbeda untuk kelompok sosial yang berbeda serta keenam motivasi utama untuk memenuhi kebutuhan sehari-hari, menerima keuntungan tradasional serta tidak berminat untuk mendapatkan penghasilan yang makin besar (Weber dalam Piotr Sztompka, 2008: 83-84).

\section{b. Masyarakat Modern}

Masyarakat modern, kehidupannya sudah ada pengaruh dari luar sehingga sifat kekeluargaan, kekerabatan dan agama sedikit mulai memudar serta tradisi dan adat-istiadat pun sudah mulai berkurang. Hal ini disebabkan cara berpikir mereka sudah rasional, berdasarkan pada perhitungan eksak yang berhubungan dengan realita dalam masyarakat (Soerjono Soekanto, 2010: 139).

Secara umum Jacobus Ranjabar (2008: 147) mengemukakan bahwa masyarakat modern dapat dikarakteristikkan sebagai berikut: pertama orang yang bersikap terbuka terhadap penemuan baru, kedua siap menerima 
perubahan-perubahan, ketiga mempunyai kepekaan terhadap masalah yang terjadi disekitarnya dan sadar bahwa masalah itu berkaitan dengan dirinya, keempat senantiasa mempunyai informasi yang lengkap mengenai pendiriannya, kelima lebih banyak berorientasi ke masa kini dan masa mendatang. Keenam senantiasa harus menyadari potensi yang ada pada dirinya dan yakin potensi itu dapat dikembangkan, ketujuh berpegang pada perencanaan dan tidak pasrah pada nasib. Kedelapan percaya pada keampuhan ilmu pengetahuan dan teknologi di dalam meningkatkan kesejahteraan, kesembilan menyadari dan menghormati hak, kewajiban serta kehormatan pihak lain dan lebih menghargai waktu untuk berkarya baik secara individu maupun kolektif.

Hal tersebut sudah barang tentu bahwa pada masyarakat modern lebih pada menggunakan pola pikirnya yang jauh lebih modern. Pola berpikirnya orang modern merujuk pada kepraktisan dalam menjalani hidupnya. Kepraktisan itu dirasa merupakan pengaruh dari berkembangnya ilmu pengetahuan dan teknologi yang sudah menjadi bagian dari masyarakatnya. Hal ini akan memberi kejelasan bahwa semakin menjadi modern, manusia makin tergantung kepada teknologi itu (Mukhlis Paeni, 2009: 2).

\section{c. Masyarakat Pedesaan}

Bentuk masyarakat ini merupakan masyarakat yang tinggal di sebuah tempat, jauh dari hiruk pikuk berbagai aktifitas keramaian maupun lainnya. Berdasarkan pernyataan itu, masyarakat desa dapat dilihat dari beberapa ciri-ciri yang diantaranya:

a. Warga pedesaan mempunyai hubungan erat dan mendalam.

b. Sistem kehidupan biasanya berkelompok berdasar kekeluargaan.

c. Warga pedesaan umumnya mengandalkan hidupnya dari pertanian.

d. Sistem gotong-royong, pembagian kerja tidak berdasarkan keahlian.

e. Cara bertani sangat tradisional dan tidak efisien karena belum mengenal mekanisasi dalam pertanian.

f. Golongan orang tua dalam masyarakat pedesaan memegang peranan penting (Nurani Soyomukti, 2010: 307-308).

Pada pengklasifikasian tersebut bahwa masyarakat pedesaan ikatan diantara warganya cukup erat yang berdasarkan pada kekeluargaan. Sifat kekeluargaan ini akan menimbulkan suatu bentuk pola kerja sama yang biasanya dilakukan. Hal ini dapat diartikan bahwa adanya sistem gotong royong tersebut bisa saja sebagai akibat dari tidak adanya keahlian pada pola pembagian kerja, yang secara tidak langsung masyarakat tersebut akan menggunakan sistem keja sama itu ketika hidup di masyarakat.

\section{d. Masyarakat Perkotaan}

Masyarakat kota merupakan sebuah masyarakat yang bersifat individulisme 
bahkan dapat dikaitkan dengan masyarakat modern. Hal demikian itu akibat dari sikap orang kota yang hanya mengurus diri sendiri tanpa ada ketergantungan pada individu lainnya. Ciri masyarakat kota seperti yang diungkapkan Soerjono Soekanto (2010: 139), yaitu pertama kehidupan keagamaan berkurang dibandingkan dengan kehidupan agama di desa, kedua orang kota pada umumnya dapat mengurus dirinya sendiri tanpa harus bergantung pada orang lain, ketiga pembagian kerja diantara warga kota juga lebih tegas dan punya batas-batas nyata, keempat kemungkinan untuk mendapatkan pekerjaan juga lebih banyak diperoleh warga kota dari pada warga Desa, kelima jalan pikiran rasional pada umumnya dianut masyarakat perkotaan. Keenam jalan kehidupan yang cepat di kota mengakibatkan pentingnya faktor waktu, dan ketujuh perubahan-perubahan sosial tampak nyata di kota sebab cenderung mudah menerima pengaruh dari luar.

Sehubungan dengan itu, bila dilihat pada jumlah penduduknya sering bertambah maupun tidak menentu serta bervariasi. Pada kenyataannya tidak menentu ini disebabkan oleh semakin banyaknya orang yang berurbanisasi di kota sehingga akan mempengaruhi kehidupan sosialnya. Perubahan sosial itu akibat dari kebebasan pengaruh dari luar. Pengaruh tersebut bisa saja mengubah masyarakat kota menjadi hedonisme, konsumerisme dan sebagainya. Proses hubungan masyarakatnya tidak intens dibandingkan masyarakat desa, dan ada kecenderungan tidak saling mengenal lainnya. Keseringan dalam berhubungan lebih berdasarkan pada faktor kepentingan. Di dalam kenyataannya, ketidakpedulian antar anggota masyarakat dirasakan adanya sikap acuh tak acuh yang sering terlihat di masyarakat perkotaan.

\section{e. Gemeinschaft dan Gesellschaft}

Menurut Ferdinand Tonnies (dalam Abu Huraerah dan Purwanto, 2006: 12) menegaskan ada dua pembagian masyarakat, yakni gemeinschaft dan gesellschaft. Masyarakat gemeinschaft adalah kelompok masyarakat yang anggotanya terikat oleh hubungan batin yang murni dan bersifat alamiah serta bersifat kekal.

Pendapat yang sama dikemukakan oleh Kamanto Sunarto (2004: 129) bahwa Gemeinschaft digambarkan sebagai kehidupan bersama yang intim, pribadi dan eksklusif serta suatu keterikatan yang dibawa sejak lahir. Geselschaft lebih pada ikatan-ikatan lahir yang bersifat pokok untuk jangka waktu yang pendek, bersifat suatu sikap dalam pikiran belaka (imaginary) serta stukturnya bersifat mekanis. Gesellschaft dapat juga mengacu pada antar anggotanya yang kurang kuat dan lebih bersifat rasional. Hal ini dapat diutarakan bahwa gemeinschaft lebih dominan ke arah masyarakat tradisional, sebab adanya suatu ikatan-ikatan yang 
masih kuat diantara anggota-anggotanya. Gesellschaft mengarah pada masyarakat modern. Pengkategorian pada masyarakat modern, dikarenakan dalam kehidupannya ikatan antar anggota agak sedikit longgar dan dalam bertindak lebih bersifat rasional, serta biasanya terbentuk dalam jangka waktu pendek.

\section{Proses Terbentuknya Masyarakat}

Terbentuknya masyarakat tidak lepas dari peran individu maupun manusia dalam kemampuannya untuk mengadakan hubungan langsung dengan individu lain. Menurut Emanuel Subangun (1994: 148) bahwa masyarakat itu tidak berdiri sendiri terlepas atau diatas individu, melainkan diciptakan sendiri oleh individu. Pendapat yang lain dikemukakan oleh Dewi Wulansari (2009: 46) bahwa terbentuknya masyarakat atau komunitas terjadi karena adanya interaksi sosial antara anggota maupun kelompok sosial melalui dua hal, pertama pertukaran pengalaman tentang pengetahuan, ketrampilan teknikal, organisasi sosial dan mengenai wilayah mereka masing-masing, kedua adanya kebutuhan yang sama dalam bentuk biologi, nilai-nilai, dan tujuan yang diajarkan oleh kebudayaan.

$$
\text { Pada kenyatannya melalui }
$$

keterjalinan interaksi tersebut, akan terlihat suatu kegiatan saling bertukar baik pikiran, pengalaman dan pengetahuan antara anggota masyarakat satu sama lain dan secara alamiah sebagai naluri dari diri manusia itu sendirinya. Adanya kebutuhan dari masing-masing manusia yang ada di kelompok itu juga berkaitan erat dengan proses awal terbentuknya masyarakat. Pada penerapannya proses interaksi itu diyakini sebagai cikal bakal terwujudnya masyarakat secara utuh, serta individu atau manusia sebagai pelaku utama dengan berbagai aktifitas yang dilakukan. Di sisi lain, adannya rasa dari diri manusia itu sendiri untuk hidup bersama dengan sesamanya juga memungkinkan terbentuk kelompok masyarakat itu sendiri.

\section{B. Interaksi Sosial}

\section{Pola Interaksi Sosial}

Interaksi itu pada dasarnya merupakan suatu hubungan timbal balik yang secara sadar untuk mengarahkan tindakan orang lain sebagai reaksi antara pihak-pihak bersangkutan. Menurut $H$. Booner (dalam Gerungan, 2009: 62) berpendapat bahwa interaksi sosial adalah hubungan antara dua atau lebih individu manusia, dimana kelakuan individu yang satu mempengaruhi, mengubah, atau memperbaiki kelakuan individu yang lain, maupun sebaliknya. Adanya interaksi sosial bilamana terwujud dalam beberapa syarat, diantaranya: pertama, adanya kontak sosial, kedua adanya komunikasi. Kaitannya dengan kedua syarat tersebut, setelah kontak sosial maupun komunikasi terjalin, tentu akan mengalami suatu interaksi sosial. Interaksi sosial tersebut akan terjadi berulang-ulang yang kemudian membentuk 
suatu pola sosial. Pola atau bentuk interaksi itu sering terjadi dalam kehidupan seharihari.

Menurut Dwi Narwoko dan Bagong Suyanto (2004: 57 \& 65) bahwa bentuk interaksi itu ada dua, yaitu pertama, proses asosiatif mencakup pada kooperasi, akomodasi, asimilasi dan amalgamasi. Kedua, yaitu proses disosiatif meliputi kompetisi, konflik maupun kontravensi. Pendapat yang lain dikemukakan oleh Alo Liliweri (2005: 129) bahwa proses tersebut meliputi pada empat bagian, yaitu pertama pertukaran sosial. Ini akan menunjukan pada sebuah pertukaran tingkah laku yang dilakukan antara anggota manusia lain guna lebih mengeratkan relasi diantara keduanya. Kedua, kerja sama. Kerja sama ini artinya, antar anggota masyarakat bekerja bersama-sama disebabkan pola pikir maupun tujuan sama, ketiga persaingan, dan keempat konflik yakni proses pertentangan satu sama lain untuk mencapai tujuan yang diharapkan.

Pola interaksi terbuka akan menyangkut pada hubungan maupun bentuk yang asosiatif. hal ini disebabkan karena tingkat intensitas ataupun seringnya anggota masyarakat dalam berinteraksi terhadap sesamanya. Pola interaksi yang tertutup, dikatakan bila tingkat keseringan interaksi jarang sekali terjadi dibandingkan pada pola terbuka itu dan tentu akan mengarah pada sebuah konflik.

\section{Pengaruh Interaksi Sosial Suku Samin Dengan Masyarakat Sekitar}

Adanya proses interaksi sosial tidak jauh dari pengaruh yang dibawa individu ke suatu kelompok, yang akan mengarah pada prasangka sosial dan sifat stereotip (Muhammad Hanif dalam Jurnal Agastya, 1 (1): 63). Menurut Baron dan Byrne (2004: 215) prasangka yaitu sikap negatif terhadap anggota kelompok tertentu berdasarkan keanggotaannya pada kelompok itu. Selain itu, Heider (dalam Bimo Walgito, 2008: 30) membagi dua macam hubungan yaitu hubungan sebagai unit (unit relation) dan hubungan sentiment (sentiment relation).

Di dalam prakteknya, ke dua hubungan itu akan terlahir di masyarakat akibat dari adanya pengaruh yang terbawa saat proses interaksi sedang berlangsung. Pada saat orang sedang berinteraksi tentu memberi dampak ke lawan interaksinya. Dampak yang diinginkan bisa saja akan menyatu dalam suatu unit, dengan demikian kesatuan dalam masyarakat akan mudah terbangun. Halnya dengan sentimen itu tadi, jika pada masa berhubungan dengan orang lain ada suatu penyimpangan maupun perbedaan tentu akan timbul perasaan tidak senang pada diri seseorang.

\section{c. Suku Samin}

Samin merupakan kelompok yang memiliki karakteristik tersendiri. Umumnya keunikan Samin terletak dipenggunakan gaya bahasa dalam kehidupan sehariharinya. Bahasa yang digunakan adalah 
bahasa jawa ngoko kasar disertai perumpaan (Andrik Purwasito dkk, 2003: 59). Keunikan lainnya pada sikap maupun tingkah laku orang Samin yang mengedepankan pada sifat kejujuran dan melarang untuk berbuat bohong, mencuri, dan berzina. Hal ini wajar jika orang Samin memiliki sifat yang puritan (Marwati dan Notosusanto, 1990: 328).

Keberadaan suku Samin dirasa sudah mengalami perubahan seiring dengan perkembangan zaman yang begitu pesat. Hal ini seperti yang diungkapkan oleh Soerjanto Sastroamodjo (2003: 31) bahwa kemurnian ajaran kesaminan mungkin hanya bisa bertahan hingga setengah atau paling banter satu abad. Adanya kemampuan untuk berhubungan dengan dunia luar juga semata-mata untuk mempertahankan keberlangsungan hidup. Keberadaan Samin yang cenderung bertempat tinggal memisah dengan dunia luar dan biasanya mendiami wilayah yang dapat dikatakan pelosok, tentu tidak akan bisa bertahan hanya mengandalkan pola kelompok itu, sehingga akan mengadakan hubungan langsung secara intensif dengan masyarakat luar demi kelangsungan hidupnya.

\section{Metode Penelitian}

Penelitian ini dilaksanakan di Dusun Jepang Desa Margomulyo Kecamatan Margomulyo Kabupaten Bojonegoro. Penelitian berlangsung selama lima bulan dari bulan Pebruari sampai Juni tahun 2012. Pengambilan data berupa sumber data primer diperoleh melalui wawancara dengan informan, dan sumber data sekunder diperoleh dari dokumen Desa Margomulyo, dokumen sejarah Samin dan bahan kepustakaan maupun jurnal ilmiah.

Pengumpulan data dilakukan dengan teknik observasi pasif yakni peneliti ketika pengamatan tidak seluruhnya ikut dalam kegiatan pada obyek penelitian, wawacara dengan beberapa informan yakni Kepala desa, Sekretaris desa, Kepala dusun, orang samin baik generasi tua maupun sekarang, dan tokoh masyarakat. Dokumen yang digunakan yaitu arsip desa Margomulyo, foto maupun catatan kesejarahan samin. Validasi data diperoleh melalui trianggulasi sumber dan teknik. Teknik trianggulasi sumber menekankan proses pengecekan data dari berbagai sumber dengan membandingkan dari sumber satu dan lain namun dalam pokok permasalahan sama.

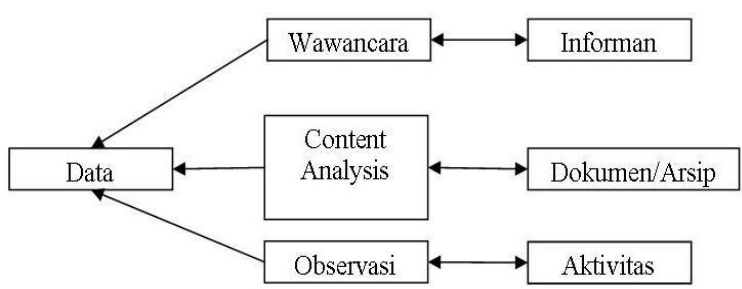

Bagan 3.1: Trianggulasi Sumber (dalam H.B. Sutopo, 2006: 94)

Trianggulasi teknik menggunakan berbagai metode untuk mengecek data kepada sumber yang sama berupa wawancara terhadap informan baik Kepala 
Desa, Sekretaris Desa, Kepala Dusun, dan orang Samin. lalu dicek dengan metode observasi dan dokumentasi.

data

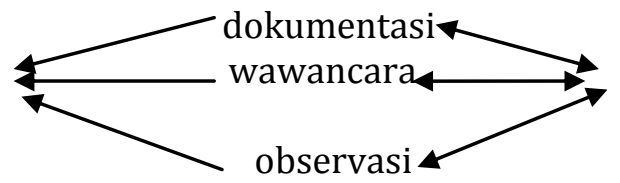

Bagan 3.2: Trianggulasi Teknik (dalam H.B. Sutopo, 2006: 96)

Analisis data yang digunakan adalah analisis data model interaktif Miles dan Huberman. Model analisis ini lebih menitikberatkan peneliti untuk tetap bergerak di antara tiga komponen itu yaitu reduksi data, sajian data, verifikasi data.

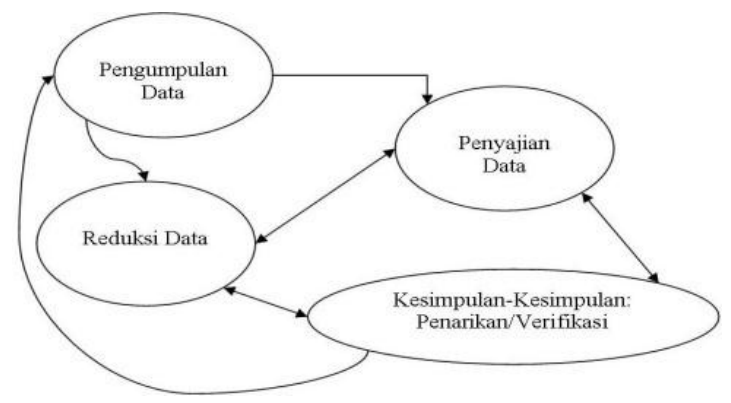

Bagan 3 : Model analisis interaktif Miles dan Huberman (dalam H.B. Sutopo, 2006: 120)

\section{Hasil Penelitian}

\section{A. Sejarah Singkat Asal Usul Masyarakat} Samin Di Dusun Jepang

Samin di wilayah Margomulyo dapat dikatakan bukan asli penduduk Dusun tersebut melainkan pindahan dari Grobogan (wawancara, Iswanto, 29 mei 2012). Ada yang mengatakan bahwa keberadaan Samin di Dusun sebagai akibat dari wilayah persebaran yang dipakai sebagai pelarian pengikut Samin Surosentiko karena masa itu keturunan orang Samin terus menjadi pusat perhatian bangsa Belanda (wawancara Sukijan, 25 Pebruari 2012). Secara historis, Samin itu berasal dari seorang yang bernama Surosentiko Samin yang berasal dari Desa Ploso Kediren Randublatug. Samin Surosentiko atau disebut Surondiko memiliki nama panggilan kecil Raden Kohar (wawancara Hardjo Kardi, 25 Pebruari 2012).

Mbah Surondiko memegang putusan empat yaitu kanjeng jawa, tinggi jawa, tunggu rakyat yang maksudnya adil dan makmur berdasarkan pancasila. tingkah laku yang diajarkan oleh mbah Surondiko jangan sampai melakukan drengki, srei, dahwen, kemeren dan semena-mena kepada manusia. Namun belum sampai selesai membahas masalah persatuan dalam melawan Belanda, mbah Surondiko tertangkap belanda tepatnya tahun 1907.

Sebenarnya sifat perlawanan yang dilakukan Samin itu sendiri diibaratkan dom sumuruping banyu, yaitu untuk melawan belanda tidak menggunakan senjata karena Surondiko sendiri tidak mau membunuh dan biasanya disebut perang sirep, artinya tidak kelihatan melawan belanda tapi sebenarnya mereka tetap melakukan 
perlawanan secara halus dan sembunyisembunyi (wawancara Hardjo Kardi, 25 Pebruari 2012). Menurut penuturan Hardjo Kardi, nama Samin berarti podho-podho, sami-sami ngamini maksudnya bersama-sama pengikutnya untuk melawan penjajah belanda. Perjuangan mbah surondiko diteruskan menantunya bernama Surokidin yang dalam perjuangannya tetap tidak mau membayar pajak kepada belanda dibantu oleh anak angkatnya yakni Surokarto Kamidin.

Surokarto Kamidin ini diperintahkan untuk tetap memberi kabar anak cucunya agar ajaran dari mbah Surondiko tetap dijalankan. Dari Surokarto Kamidin ini penyebarannya sampai ke wilayah Dusun Jepang bersama anak lelakinya bernama Hardjo Kardi. Di Dusun ini mereka tetap menjalankan apa yang diperintahkan dari sesepuhnya sehingga pengikutnya semakin banyak.

Sampai pada suatu waktu Surokarto Kamidin wafat sekitar tahun 1986 (keterangan Hardjo Kardi), dan kepemimpinan dipimpin oleh Hardjo Kardi yang saat ini masih ada di Dusun Jepang. Seiring berjalannya waktu, ilmu pengetahuan Hardjo kardi semakin bertambah, serta dalam menjalani hidup beliau mempunyai empat pedoman yaitu merah, hitam, kuning, putih, kemudian dipecah menjadi delapan yaitu pangganda, pangrasa, pangrungon, pangawas. Menurut penuturan Hardjo Kardi (wawancara 25 Pebruari 2012), bahwa setelah Indonesia telah merdeka, pengikutnya sudah mulai berubah, artinya sekarang dipimpin oleh bangsa sendiri sehingga komunitas Samin di Jepang sudah mengikuti aturan yang diberikan pemerintah lainnya.

B. Keberadaan Masyarakat Samin dari tahun 1990 Sampai 2012

Keberadaan masyarakat Samin di Dusun Jepang dalam kurun waktu itu diyakini sudah mengalami masa transisi dari tradisional menuju modernisasi. Pada dasarnya mereka telah melepaskan atribut kesaminannya meskipun hanya beberapa saja yang masih kental terhadap identitas Saminisme itu, misalnya budaya yang masih berbeda dengan masyarakat yaitu ketika orang Samin mempunyai hajat, mereka tidak mau menerima sumbangan berupa uang melainkan harus barang pokok seperti beras atau yang lainnya (keterangan Nuryanto, 28 Mei 2012).

Ini mengindikasikan fase tersebut orang Samin telah jauh mengalami perubahan yang cukup signifikan, artinya proses menjadi manusia modernisasi serta kemauan membaur dengan masyarakat sudah terjadi. Pada tahun 1990-an masyarakat Samin bisa disebut sebagai masa transisi menuju pada masyarakat yang lebih 
maju. pada tahun tersebut kehidupannya sudah sama dengan masyarakat umum sebab ada kemauan untuk membaur dengan masyarakat lainnya. Sebenarnya pada awal 1990-an jumlah orang Samin yang masih memegang teguh ajarannya cenderung banyak. Hal ini disebabkan ajaran yang diterapkan masih terjaga keasliannya, dan hal itu dipengaruhi letak tempat tinggalnya masih pelosok dan untuk menuju kesana harus bersusah payah karena jalannya masih belum di sepenuhnya aspal (Observasi 14 Pebruari 2012),

Saat sekarang orang Samin yang kental dengan ajaran Samin berkisar 34 kepala keluarga (wawancara Iswanto, 29 Mei 2012), diantaranya seperti Hardjo kardi (kepala suku), Lastro, Darmo, Kasmo, Sarimah, Sampan, dan Samidi (keterangan Sukijan, 24 Pebruari 2012). Secara ekonomi keturunan Samin sangat mapan, sebab selain bercocok tanam mereka juga memelihara ternak seperti sapi di rumahnya. Kehidupan orang Samin telah mendapat perhatian dari pemerintah terutama program pembangunan daerah terpencil yang memprioritaskan pada warga Samin. Kurun waktu 1990 sampai 2012, ada berbagai bantuan bersifat meteriil, otomatis membantu perbaikan kehidupan di Dusun itu dan khususnya warga Samin. Bantuan itu dalam bentuk hibah ternak, kandang, pupuk, benih- benih tanaman, mck dan sekarang sudah ada balai budaya berfungsi sebagai tempat pertemuan antara Samin dan masyarakat lain.

Untuk menunjang akses masuk ke tempat tinggal Samin, pemerintah memberi bantuan berupa aspal jalan (1996/1997), mesin diesel termasuk selep (1996/1997) serta listrik pada tahun 1998. perubahan warga Samin untuk membaur dengan masyarakat didasari karena banyak kunjungan dari kalangan intelektual dari berbagai daerah maupun luar negeri, pejabat, dan dari kraton Jogjakarta, sehingga secara tidak langsung muncul keterbukaan dengan masyarakat lain. SDM Samin cenderung lebih berkembang terutama keturunan Samin saat ini, hal ini juga didukung karena secara SDM mereka sudah bersekolah bahkan sampai tingkat SMA, ada yang menjadi pegawai negeri dan polisi. Hal ini diyakini akan mengubah pola pikir dalam berhubungan dengan masyarakat. Namun demikian keturunan Samin yang tua tetap dapat dikatakan berpola pikir maju tetapi kekentalan ajaran Samin masih sangat kentara.

\section{Pembahasan}

Keberadaan Suku Samin dalam perkembangannya di Dusun Jepang sejauh ini memang menjadi salah satu hal yang perlu dicermati, dimana masalah tansisi dari 
gaya hidup tradisional menjadi modernisasi, sehingga mampu menerima untuk membuka diri dengan masyarakat lain. hakekatnya dalam berinteraksi, tidak langsung secara menyeluruh, apalagi ada kesan mereka sedikit takut bilamana keaslian tradisi mereka terpengaruh oleh masyarakat lainnya yang saat itu telah menjadi antek-antek bangsa Belanda. Namun mereka perlahan-lahan telah bersedia ketika ada orang yang bukan warga Samin untuk membaur dan kesan ketakutan sebelumnya dirasakan, sedikit mulai melunak. Proses interaksi menjadi terbuka mulai berkisar tahun 1990-an dimana Suku Samin mampu beradaptasi dengan segala perubahan yang ada. Pada tahun 2000-an sampai sekarang dapat dikatakan sudah berada pada zaman modern, bisa dikatakan Suku Samin telah sama dengan masyarakat biasa, dalam artian bentuk interaksinya sudah tidak canggung lagi seperti tatkala pada masa tahun 1990-an.

Ada hal lain bisa dikatakan, Samin telah modern seperti pertama, Tingkat perekonomian diatas rata-rata. ini dibuktikan kebanyakan orang-orang Samin dipandang dari segi ekonomi cukup mapan, Kedua, rumah tempat tinggal masyarakat Samin sudah dikatakan layak huni. artinya sebelumnya rumah orang Samin dindingnya hanya beralaskan pelepah kayu jati dan seadanya, namun sekarang banyak yang dibuat rumah berdinding tembok, dan terkadang rumahnya sudah berkeramik serta perkakasnya telah banyak yang modern, ketiga dari segi bercocok tanam sudah tersentuh oleh modernisasi dibuktikan telah mengenal cocok tanam dengan sistem Agrobisnis.

Proses interaksi dilakukan di berbagai tempat dan kegiatan baik kegiatan lingkungan warga seperti gotong royong, Arisan warga, Musyawarah Desa dan dalam bidang pertanian seperti bercocok tanam di ladang maupun menanam padi di sawah. adapun Faktor Yang Mempengaruhi Interaksi Suku Samin Dengan Masyarakat Sekitar diantaranya:

\section{a. Adanya Tuntutan Zaman}

Adanya perubahan zaman tentu dirasa kelompok minoritas seperti suku Samin itu sendiri juga tetap ingin eksis sepanjang zaman, artinya kemauan dalam membaur dengan masyarakat didasari keinginan untuk bertahan hidup dalam masyarakat seiring dengan perkembangan zaman dari waktu ke waktu.

\section{b. Sumber Daya Manusia Anak \\ Keturunan Samin Setiap Tahun Meningkat}

pengaruh SDM keturunan Samin akan mengakibatkan kemampuan warga Samin ketika berinteraksi dengan masyarakat lainnya. ini disebabkan masa sekarang keturunan Samin sudah banyak mengenyam bidang pendidikan baik dari SD maupun sampai SMA. 


\section{c. Keberadaan Ketokohan Hardjo Kardi (Pemangku Adat Samin)}

Keberadaan Hardjo Kardi yang kharismatik dan Pola pikir Hardjo Kardi bila dibandingkan dengan sesepuh lainnya, telah jauh lebih modern. ini dapat diartikan dengan kepemimpinan Hardjo Kardi yang mau bergaul dengan masyarakat secara otomatis akan dianut oleh pengikutnya sehingga mempermudah untuk bergaul dengan warga sekitar.

Dari pengantar tersebut dikatakan proses interaksi yang sering dilakukan hanya beberapa saja yakni berupa bentuk asosiatif dan disosiatif, dan adapun penjabarannya sebagai berikut:

\section{Proses Asosiatif}

\section{a) Kerja Sama}

Di dalam bentuk interaksi ini baik suku Samin dengan masyarakat pada umumnya sering melakukan kerja sama dalam hal gotong royong antar anggota masyarakatnya, misalnya gotong-royong membantu pembangunan rumah warga dengan sistem sambatan. Selain itu kerja bakti untuk membantu perbaikan sarana dan prasarana lingkungan seperti, pertama pembangunan akses jalan di Dusun Jepang dengan pengaspalan yang didapat dari bantuan pemerintah. Kedua, kerja sama dalam hal membangun Balai Budaya yang nantinya tempat ini akan dijadikan sebagai pusat informasi Suku Samin.
Ketiga, sinoman (pladen) saat ada masyarakat yang punya hajat. Hal ini khusunya keturunan orang Samin generasi muda yang sering terlibat dalam hal membantu sinoman ini, namun Samin sepuh juga membantu sebatas memberi komando dalam acara tersebut (keterangan Iswanto, $29 \mathrm{Mei}$ 2012).

\section{b) Akomodasi}

Bentuk interaksi ini berupa adanya sebuah rasa toleransi misalnya berkaitan dengan upacara keagamaan. Sebenarnya warga Samin secara tradisi memiliki cara tersendiri dalam peribadatan dan tidak terlihat oleh masyarakat awam. Namun ketika ada acara keagamaan secara umum mampu menghormati dan terkadang tidak ada pengusikan terhadap pelaksanaan acara itu. Di samping itu perbedaan pendapat ketika dalam musyawarah warga Samin sering menerima hasil keputusan rapat tersebut. Di samping itu juga menjalankan bentuk akomodasi besifat compromise (persetujuan) dimana ketika menghadapi suatu permasalahan jalan ini sering mereka tempuh. ini dibuktikan ketika ada kesalahpahaman seperti sengketa pengukuran tanah yang terkadang dari pihak orang Samin selalu kukuh pada pendapatnya serta lahan itu tidak mau disertifikatkan, dan kemudian diajak musyawarah selanjutnya mereka akhirnya mau menerima putusan itu. 


\section{Bentuk Disosiatif}

Pada dasarnya bentuk disosiatif dilatarbelakangi perbedaan-perbedaan pendapat. Konflik yang sering terlihat adalah saat adanya berbagai bantuan seperti ternak, pupuk yang diprioritaskan pada masyarakat Samin. Seyogyanya bantuan yang diajukan dari Pemerintah itu seharusnya juga mencakup ke seluruh lingkungan Dusun Jepang. Misalnya saja ada bantuan sapi sebanyak 300 ekor untuk lingkungan Samin namun bagi orang Samin yang berhak memelihara adalah orang Samin. Namun menurut perangkat pemerintahan, seharusnya bantuan sapi tersebut lebih baik diberikan ke warga Dusun itu yang belum mempunyai sapi sebab bantuan ini bersifat bersama, karena di Dusun Jepang terkenal dari adanya orang Samin, maka mereka mengklaim bantuan tersebut lebih baik untuk Samin saja (keterangan Sukijan, 25 Pebruari 2012).

Melihat kenyataan itu tentu akan terjadi kecemburuan sosial antara masyarakat terhadap orang Samin sebab orang Samin selalu bersikukuh dalam berpendapat, tentu hal ini mengakibatkan ada rasa ketidaksukaan terhadap orangorang Samin dan secara psikologi akan sedikit terjadi konflik meskipun tidak sampai mengubah tatanan bermasyarakat.

Adanya interaksi antar sesama manusia baik itu pada masyarakatnya, individu ataupun antar kelompok secara otomatis akan berdampak pada antar warga
Samin maupun masyarakat sekitar. Dampak tersebut bisa saja mengarah pada hal yang positif maupun pengaruh negatif. Adapun pengaruh itu dapat dijelaskan sebagai berikut.

\section{Pengaruh Interaksi Bersifat Positif}

\section{a) Bagi Masyarakat Samin}

pengaruh konkret pada orang Samin setelah berinteraksi, tentu akan ada sebuah perubahan pola tingkah laku yang terjadi dalam kehidupan masyarakat Samin itu sendiri yang terwujud dalam beberapa hal sebagai berikut: Pertama, masa dahulu sebelum membaur dengan masyarakat, pakaian orang Samin memiliki ciri khas tersendiri yakni memakai kaos oblong, celana sebatas lutut dan selalu memakai iket kepala, akan tetapi pada masa sekarang baik itu Samin sepuh maupun generasi muda telah mengalami perubahan sehingga mau memakai pakaian yang ada pada masyarakat saat sekarang. Perlu dicatat bahwa tradisi pakaian tradisonal dipakai hanya dalam kegiatan masyarakat Samin saja, itu pun oleh Samin sepuh.

Kedua adanya pendatang juga mempengaruhi kehidupannya dan tingkah laku orang Samin, tentu akan perubahan perilaku terhadap penggunaan teknologi berupa handphone, televisi dan lainnya sehingga kebanyakan orang Samin 
masa sekarang telah mau menerima budaya seperti penggunakan handphone sebagai media komunikasi maupun televisi sebagai media informasi. Ketiga, dalam hal perkawinan. Orang Samin kecenderungan memiliki konsep berbeda ketika melaksanakan sebuah pernikahan. Dulu hal ini dibuktikan tatkala orang samin mau menikah, mereka mempunyai ciri khas tersendiri yang tidak mau mengikuti aturan pemerintah seperti tidak mencatatkan secara formal di KUA. Namun setelah mereka membaur dengan masyarakat tentu akan mempengaruhi tingkah lakunya ini dibuktikan kemauan mereka mengikuti aturan pemerintah dengan mencatatkan diri pada lembaga pernikahan yaitu di Kantor Urusan Agama (KUA).

\section{b) Bagi Masyarakat Sekitar}

Pengauh interaksi tentu juga akan berdampak bagi masyarakat misalnya akan mengetahui karakter orang Samin dengan memiliki kemandirian yang teguh sehingga dengan paham akan karakter mereka secara langsung akan diikuti oleh masyarakat. Selain itu akan terpengaruh oleh sifat kejujuran orang Samin, dalam artian orang Samin yang cenderung memilki kejujuran dan ulet tentu mereka secara otomatis akan sedikit mengikuti pola yang dikembangkan oleh Samin itu sendiri. Hal lain tentu dengan karakter orang samin yang giat dalam pekerjaan akan menjadi acuan bagi masyarakat dalam hal ketika melakukan pekerjaan apapun baik ketika bercocok tanam di sawah maupun di ladang maupun yang lainnya.

\section{Pengaruh Bersifat Negatif}

a) Bagi Masyarakat Samin

Dalam bentuk ini akan melunturkan tradisi maupun kekhasan yang sering terjada dengan baik. Melunturnya tradisi itu sekarang bisa dilihat pada peninggalan budaya pakaian khas Samin baik dari generasi tua maupun muda telah mereka tinggalkan. Melihat kenyataan tersebut tradisi yang mereka jaga selama ini sekarang sudah jarang terlihat namun hanya generasi tua yang sering memakai ciri khas itu hanya pada acara-acara tertentu. Selain itu prinsip kejujuran cenderung sedikit berkurang sebab dalam berinteraksi mereka juga mengadakan kerjasama dalam hal sector ekonomi tentu mereka mengadakan jual beli dan sudah barang tentu akan mencari untung dengan tujuan untuk pemenuhan kebutuhan hidup.

\section{b) Bagi Masyarakat Sekitar}

Dengan semakin seringnya bergaul dengan masyarakat Samin tentu juga akan membawa pengaruh 
negatif walaupun sangat sedikit. Hal ini dapat terlihat ketika terbawa pengaruh oleh cara bicaranya orang Samin yang terkadang menggunakan bahasa ngoko kasar sehingga sering diikuti oleh yang lain. Disamping itu ada sedikit rasa ketidaksukaan bila sering diolok-olokan misalnya ketika ada tingkah laku yang tidak pas langsung dibuat bahan tertawaan sehingga akan sedikit memiliki rasa malu. Hal ini mengindikasikan bahwa secara umum bahwa kehidupan sudah layaknya seperti masyarakat sekarang ini, artinya dampak negatif ini tidak mempengaruhi kesemua hidup setiap individu dalam masyarakat sekitar.

\section{Simpulan Dan Saran}

\section{A. Simpulan}

Pada dasarnya bentuk interaksi yang terjadi antara suku Samin dengan masyarakat sekitarnya berupa asosiatif maupun bentuk disosiatif. Bentuk asosiatif ini bersifat positif berupa kerja sama dalam hal gotong royong seperti membuat akses jalan dari aspal, warga punya gawe (sambatan) membuat rumah. Di samping itu adanya akomodasi dalam menetralisir perselisihan dari perbedaan pendapat dan ketika ada kesalahpahaman mereka mau diajak musyawarah dan membuat perjanjian untuk kepentingan bersama. Pada bentuk disasoatif muncul kecemburuan sosial, khususnya bantuan dari Pemerintah, seyogyanya untuk kepentingan bersama namun menguntungkan salah satu pihak sehingga terjadi muncul konflik antar individu.

Interaksi tersebut juga ada pengaruh baik bersifat positif maupun negatif. Sifat positif bagi orang Samin seperti pola pikir, gaya hidup akan berkembang sebab mau menerima pandangan dari luar, sedangkan masyarakat akan terpengaruh sifat kejujuran atau kekhasan lainnya dari karakter orang Samin. Pengaruh negatif bagi Samin dengan mengikuti pergaulan masyarakat luas, mereka juga akan sedikit terpengaruh dan akan mengikuti perkembangan yang ada, sehingga tradisi mereka akan luntur dengan pola perubahan baru dan sedikit mulai meninggalkannya. Bagi masyarakat biasa, ada prasangka terhadap mereka dan berhati-hati dalam berkomunikasi dengan orang Samin.

\section{B. Saran}

\section{Bagi Pemerintah Kabupaten} Bojonegoro

Dengan keberadaan Suku Samin diharapkan pemerintah pusat mampu memberi perhatian penuh terhadap keberlangsungan hidupnya. Perhatian tersebut dapat diberikan melalui program-program pemerintah yang mengarah pada pemberdayaan Sumber Daya Manusia baik materiil maupun non materiil, sehingga kesejahteraan 
khususnya masyarakat Samin akan terpenuhi.

\section{Bagi Dinas Pariwisata dan}

\section{Kebudayaan}

Diharapkan dinas yang terkait juga memberi perhatian sepenuhnya bagi masyarakat Samin, sebab Samin adalah kaum minoritas yang jarang sekali ditemui dan tentu akan menjadi kebanggaan tersendiri karena merupakan bentuk dari kearifan lokal di wilayah Bojonegoro yang perlu ada pelestariannya. Disamping itu diharapkan pula bagi dinas pariwisata untuk mengembangkan keunikan budaya tersendiri yang ada di masyarakat Samin dan juga perlu ada tindakan untuk dipromosikan maupun diperkenalkan ke masyarakat luas, sehingga nantinya akan menjadi sebuah icon pariwisata khususnya di daerah Bojonegoro.

\section{Dinas Kesehatan Setempat}

Keterkaitan dengan dinas kesehatan ada, hal ini dimaksudkan agar dinas yang terkait memberikan penyuluhan-penyuluhan dalam hal pola hidup sehat ataupun yang lain. Hal ini diperlukan sebab kecenderungan masyarakat samin jauh dari hiruk-pikuk lingkungan secara luas, bisa dikatakan mereka tinggal dipemukiman terisolir (pedalaman) yang cenderung kehidupannya tidak teratur, sehingga adanya peran dinas terkait dalam penyuluhan agar masyarakat khususnya samin dapat memperoleh informasi yang nantinya akan bermanfaat saat keberlangsungan hidup mereka.

\section{Daftar Pustaka}

Abdulsyani. 2012. Sosiologi: Skematika, Teori, dan Terapan. Jakarta: PT Bumi Aksara.

Abraham Nurcahyo dan Yudi Hartono. 2008. Pengantar Antropologi. Magetan: Lembaga Edukasi Swastika.

Abraham Nurcahyo, dkk. 2009. Ilmu Sosial dan Budaya Dasar. Magetan: LESwastika Press.

Abu Ahmadi. 2004. Sosiologi Pendidikan. Jakarta: PT. Rineka Cipta.

Abu Huraerah dan Purwanto. 2006. Dinamika Kelompok: Konsep dan Teori. Bandung: PT Refika Aditama.

Alo Liliweri. 2009. Prasangka Dan Konflik: Komunikasi Lintas Budaya Masyarakat Multikultur. Yogyakarta: Lkis.

Amri Marzali. 2007. Antropologi dan Pembangunan Indonesia. Jakarta: Kencana.

Andrik Purwasito. 2003. Agama Tradisional: Potret Kearifan Hidup Masyarakat Samin dan Tengger. Yogyakarta: Lkis.

Arni Muhammad. 2004. Komunikasi Organisasi. Jakarta: Bumi Aksara.

Bambang Rudito dan Melia Famiola. 2008. Social Maping Metode Pemetaan Sosial: Teknik memahami suatu masyarakat atau komuniti. Bandung: Rekayasa Sains.

Baron dan Byrne. 2004. Psikologi Sosial. Jakarta: Penerbit Erlangga.

Bimo Walgito. 2008. Psikologi Kelompok. Yogyakarta: C.V. Andi Offset.

Burhan Bungin. 2009. Sosiologi Komunikasi: Teori, Paradigma, dan Diskursus Teknologi Komunikasi di Masyarakat. Jakarta: Kencana.

Dadang Supardan. 2008. Pengantar Ilmu Sosial Sebuah Kajian Pendekatan Struktural. Jakarta: Bumi Aksara.

Dany dan Nugrohadi. 2011. Pengantar Sosiologi Dasar. Jakarta: PT Prestasi Pustakaraya. 
Dewi Wulansari. 2009. Sosiologi: Konsep Dan Teori. Bandung: PT Refika Aditama.

Dja`Man Satori dan Aan Komariah. 2011. Metodologi Penelitian Kualitatif. Bandung: Alfabeta.

Dwi Narwoko dan Bagong Suyanto (Eds.). 2010. Sosiologi: Teks Pengantar dan Terapan. Jakarta: Kencana.

Elly M. Setiadi, dkk. 2007. Ilmu Sosial dan Budaya Dasar. Jakarta: Kencana.

Emmanuel Subangun. 1994. Dari Saminisme ke Posmodernisme. Yogyakarta: CRI Alocita

Gerungan. 2009. Psikologi Sosial. Bandung: PT. Refika Aditama.

Hartono dan Arnicun Aziz. 1999. Ilmu Sosial Dasar. Jakarta: PT Bumi aksara.

Hassan Shadily. 1993. Sosiologi untuk Masyarakat Indonesia. Jakarta: PT Rineka Cipta.

H.B. Sutopo. 2006. Metodologi Penelitian Kualitatif. Surakarta. Universitas Sebelas Maret.

Herimanto dan Winarno. 2011. IImu Sosial dan Budaya Dasar. Jakarta: Bumi Aksara.

Husaini Usman dan Purnomo Setiady. 2004. Metodologi Penelitian Sosial. Jakarta: PT. Bumi Aksara.

Jacobus Ranjabar. 2008. Perubahan Sosial Dalam Teori Makro Pendekatan Realitas Sosial. Bandung: Alfabeta.

Joko Subagyo. 2004. Metode Penelitian dalam Teori dan Praktek. Jakarta: PT Rineka Cipta.

Kamanto Sunarto. 2004. Pengantar Sosiologi. Jakarta: Lembaga Penerbit Fakultas Ekonomi Universitas Indonesia.

Khairudin. 2000. Pembangunan Masyarakat Tinjauan Aspek Sosiologi, Ekonomi, dan Sosial. Yogyakarta: Liberty Yogyakarta.

Koentjaraningrat. 2009. Pengantar Ilmu Antropologi Edisi revisi 2009. Jakarta: Rineka Cipta.

Lauer, Robert H. Tanpa Tahun. Perspektif Tentang Perubahan Sosial. Terjemahan oleh Alimandan S.U. 2003. Jakarta: PT Rineka Cipta.

Leo Suryadinata, dkk. 2003. Penduduk Indonesia Etnis dan Agama dalam Era
Perubahan Politik. Jakarta: Pustaka LP3ES Indonesia.

Lexi J. Moleong. 2007. Metodologi Penelitian Kualitatif. Bandung: PT Remaja Rosdakarya.

Marwati Djoned dan Notosusanto. 1990. Sejarah Nasional Indonesia IV. Jakarta: Balai Pustaka.

Muhammad Hanif. 2011. Peranan Wanita Desa Soco Bendo Magetan Dalam Mengatasi Dampak Psikologi Sosial Pasca Madiun Affair 1948 (Studi Sejarah Sosial). Agastya. No.1 Tahun I Januari 2011: 61-79.

Muhammad Teguh. 1999. Metodologi Penelitian Ekonomi Teori dan Aplikasi. Jakarta: PT. Rajagrafindo Persada.

Mukhlis PaEni. 2009. Sejarah Kebudayaan Indonesia Sistem Sosial. Jakarta: PT Raja Grafindo Persada.

Munandar Soelaeman. 2011. Ilmu Sosial Dasar Teori dan Konsep Ilmu Sosial. Bandung: PT Refika Aditama.

Nasikun. 2007. Sistem Sosial Indonesia. Jakarta: PT Raja Grafindo.

Nurani Soyomukti. 2010. Pengantar Sosiologi Dasar Analisis, Teori, \& Pendekatan Menuju Analisis MasalahMasalah Sosial, Perubahan Sosial, \& Kajian-Kajian Strategis. Yogyakarta: AR-Ruzz Media.

Nursid Sumaatmadja. 2010. Manusia dalam Konteks Sosial, Budaya, dan Lingkungan Hidup. Bandung: $\mathrm{Cv}$. Alfabeta.

Patton, Michael Quinn. 2009. Metode Evaluasi Kualitatif. Yogyakarta: Pustaka Belajar.

Purwantini, dkk. 2000. Tradisi Lisan Suku Samin di Daerah Pedalaman Kabupaten Bojonegoro. dalam Laporan DIP Universitas Airlangga: Fakultas Sastra Universitas Airlangga.

Soerjanto Sastroatmodjo. 2003. Masyarakat Samin: Siapakah Mereka?. Yogyakarta: Narasi.

Soerjono Soekanto. 2010. Sosiologi Suatu Pengantar. Rajawali: PT Raja Grafindo Persada.

Sri Wiryanti dan Kisyani. 2010. Situasi Ragam Wicara Komunitas Adat Samin: Kajian Etnopragmatik. dalam Laporan 
Penelitian Kerjasama Antar Perguruan Tinggi (HibahPekerti): Universitas Airlangga.

Sugiono. 2012. Memahami Penelitian Kualitatif. Bandung: Alfabeta.

Suharsimi Arikunto. 2010. Prosedur Penelitian. Jakarta: Rineka Cipta.

Sunaryo. 2004. Psikologi untuk Keperawatan. Jakarta: EGC.

Supardi. 2011. Dasar-dasar Ilmu Sosial. Yogyakarta: Ombak.

Suratman, dkk. 2011. Ilmu Sosial dan Budaya Dasar. Malang: Intimedia.

Syahrial Syarbaini dan Rusdiyanta. 2009. Dasar-dasar Sosiologi. Yogyakarta: Graha Ilmu.

Sztompka, Piotr. 2008. Sosiologi Perubahan Sosial. Jakarta: Prenada.

Tanpa Nama. 2012. Data Monografi Desa/Kelurahan Margomulyo: Bojonegoro

Titi Mumfangati, dkk. 2007. Kearifan Lokal Di Lingkungan Masyarakat Samin Kabupaten Blora Jawa Tengah: Kantor Pariwisata dan Kebudayaan Blora.

Tri Widiarto, dkk. 2000. Dasar-dasar Sosiologi I. Salatiga: Jurusan Sejarah FKIP Universitas Kristen satya wacana.

Ulber Silalahi. 2010. Metode Penelitian Sosial. Bandung: PT Refika Aditama.

Vitalis, DS. 2010. Pengaruh Pendidikan Seksual Terhadap Pengembangan Sikap Berkomunikasi Bagi Siswa Sekolah Menengah. Jurnal Pendidikan. No. I Tahun XVI Juni 2010: 72-91.

Wiryanto. 2004. Pengantar Ilmu Komunikasi. Jakarta: PT. Grasindo.

Yudi Hartono. 2011. Pembelajaran yang

Multikultural untuk Membangun Karakter

Bangsa. Agastya. No. 01 Tahun I Januari

2011: 27-43. 